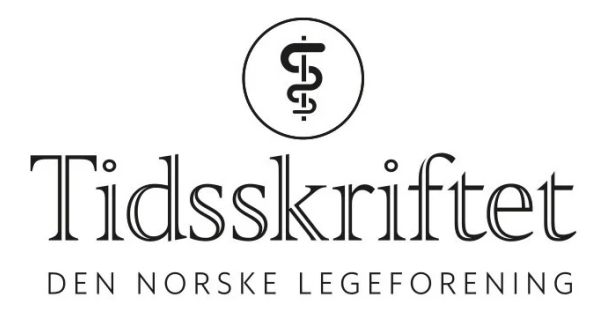

\title{
Enhver medisinstudents mareritt?
}

TIDLIGERE I TIDSSKRIFTET

SYNNE LOFSTAD

synne.lofstad@hotmail.com

Redaksjonssjef i Æsculap

Kan du basal førstehjelp? Det kunne ikke undertegnede tidlig i studiet. Vi hadde ett førstehjelpskurs det første semesteret, for så å studere i flere år uten repetisjon.

Situasjonsbeskrivelsen fra 1995 lyder derfor ubehagelig velkjent, og det var ikke sjelden at tanken på livløse barn og besteforeldre i stans fikk meg til å skjelve i buksene (Æsculap 1995; 75(3): 9).

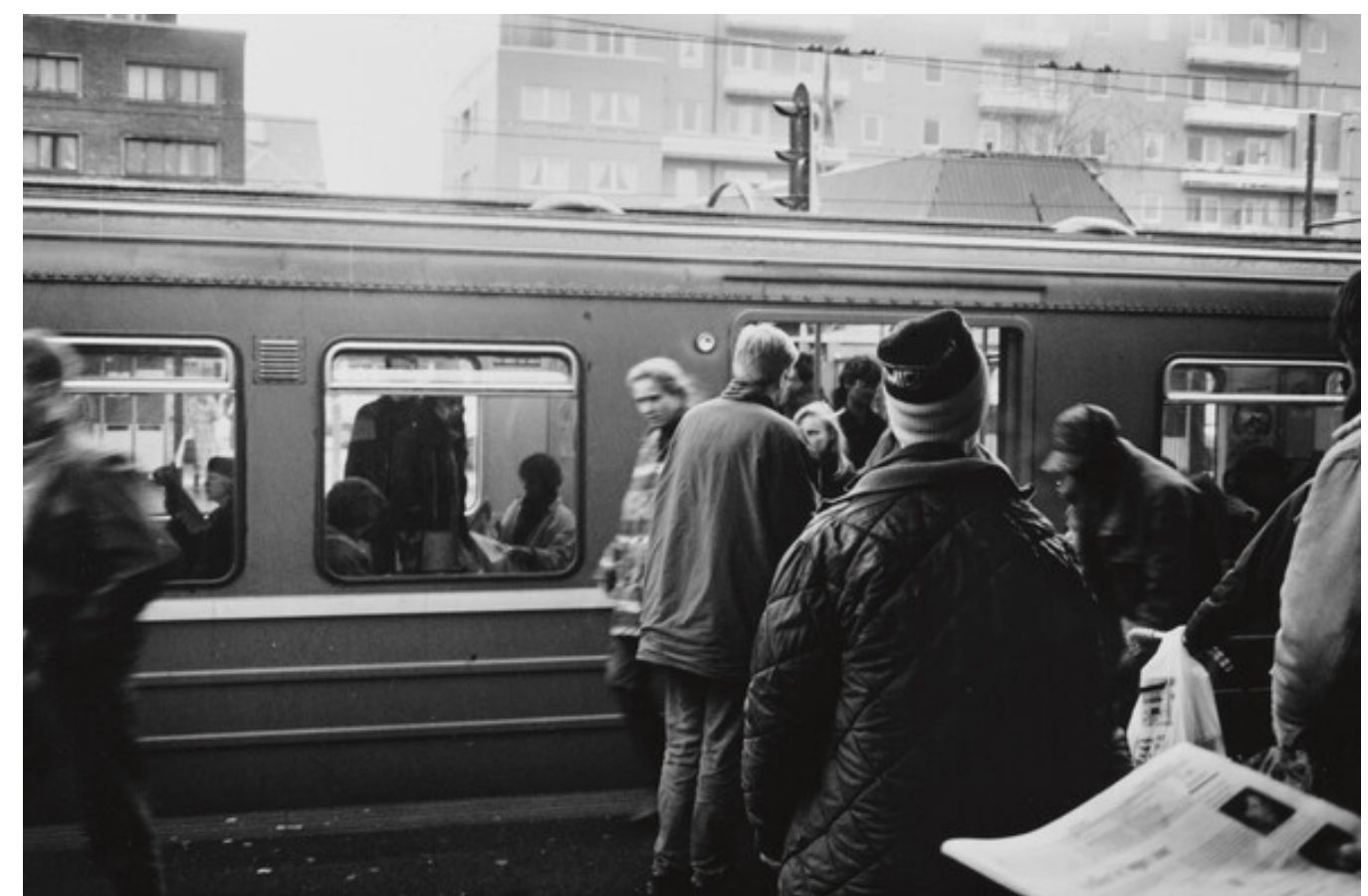

Illustrasjonsfoto: P. A. Risnes jr. / Arbeiderbevegelsens arkiv og bibliotek

STANS på bane 4 ! 
Tirsdag ettermiddag. Bane 4 ruller inn på Majorstua stasjon. Plutselig faller en eldre mann i golvet. Folk skriker opp, stimler sammen rundt den livløse kropp. Er han død?

Er det noen lege her? ropes det. Tankene spinner omkring. Lege, nei, snarere halvstudert legestudent, husker ikke når vi hadde kurs i førstehjelp. Jeg venter et kvart sekund og håper at en eller annen skal melde seg. En eller annen, en eller annen!!

«Er det noen lege her? ropes det»

Jeg er sykepleier, sier ei dame. Har noen et speil? Gudskjelov, tenker jeg, et menneske som kan noe. Men hvorfor står det så mange rundt og glaner? Selvsagt! Det er sosialpornografi in practicum. Det er disse menneskene som leser Se og Hør hos tannlegen.

Neste tanke: Hvorfor i svarte er det så lenge siden vi har hatt førstehjelpskurs på studiet? For å kjenne seg rimelig trygg på prosedyren bør førstehjelp drilles en gang i året.

Mikroskopisk utseende av piece meal-nekrose er viktig, bevares, men dette er viktigere.

Livsviktig, faktisk. Plutselig kjenner jeg sinne sige innover meg: Jeg føler meg så sikker på at fakultetet ikke vil gjøre noe med det.

Erlend Hem

Publisert: 28. august 2020. Tidsskr Nor Legeforen. DOI: 10.4045/tidsskr.20.0565

(C) Tidsskrift for Den norske legeforening 2023. Lastet ned fra tidsskriftet.no 26. april 2023. 